\title{
New Insights into the Distribution, Physiology and Life Histories of South American Galaxiid Fishes, and Potential Threats to This Unique Fauna
}

\author{
Víctor Enrique Cussac ${ }^{1, *(\mathbb{D}}$, María Eugenia Barrantes ${ }^{2}{ }^{\mathbb{D}}$, Claudia Clementina Boy ${ }^{2}$, \\ Konrad Górski ${ }^{3,4}{ }^{(0)}$, Evelyn Habit ${ }^{5}$, , María Eugenia Lattuca ${ }^{2}$ and Javier Hernán Rojo ${ }^{2}$ (D) \\ 1 Instituto Patagónico de Tecnologías Biológicas y Geoambientales (IPATEC), Universidad Nacional del \\ Comahue-CONICET, Bariloche 8400, Argentina \\ 2 Centro Austral de Investigaciones Científicas (CADIC) - Consejo Nacional de Investigaciones Científicas y \\ Técnicas (CONICET), Ushuaia 9410, Argentina; eugebarrantes@gmail.com (M.E.B.); \\ claudiaboy@cadic-conicet.gob.ar (C.C.B.); elattuca@cadic-conicet.gob.ar (M.E.L.); \\ javierhrojo@gmail.com (J.H.R.) \\ 3 Instituto de Ciencias Marinas y Limnológicas, Facultad de Ciencias, Universidad Austral de Chile, \\ Valdivia 5090000, Chile; konrad.gorski@uach.cl \\ 4 Facultad de Ciencias, Universidad Católica de la Santísima Concepción, Concepción 4030000, Chile \\ 5 Departamento de Sistemas Acuáticos, Facultad de Ciencias Ambientales y Centro EULA-CHILE, \\ Universidad de Concepción, Concepción 4030000, Chile; ehabit@udec.cl \\ * Correspondence: cussacve@comahue-conicet.gob.ar; Tel.: +54-929-4451-2920
}

Received: 3 March 2020; Accepted: 15 April 2020; Published: 4 May 2020

\begin{abstract}
South American galaxiids occupy both Patagonia and the ichthyogeographic Chilean Province, encompassing glacial Andean deep lakes, shallow plateau lakes, reservoirs, short Pacific rivers and long Atlantic rivers. The total fish fauna includes 29 species, comprising Neotropical fishes (siluriforms and characids), galaxiids, percichthyids, atherinopsids and mugilids, two lamprey species, and several exotic fishes (salmonids, Gambusia spp. and common carp). The family Galaxiidae shares a common ancestry with the Gondwanan temperate fish fauna, played a major role in the post-glacial colonization of Andean lakes and streams, and contributes key species to the food webs. Galaxiid species occupy an enormous latitudinal gradient, show a wide variety of life history patterns and are the southernmost native freshwater fishes of the world. Knowledge of South American galaxiids has improved notably, but new challenges arise due to climate change, biological invasions, damming, aquaculture and contamination. In this changing environment, the future of South American galaxiids should be carefully considered as a legacy of the old Gondwana and a unique attribute of the freshwaters of southern South America.
\end{abstract}

Keywords: Aplochiton; Brachygalaxias; Galaxias; life history; South America; temperature

\section{Introduction}

South American galaxiid fishes occupy most of Patagonia [1] and the south of the icthyogeographic Chilean Province [2], between $33^{\circ} 08^{\prime} \mathrm{S}$ and $55^{\circ} 35^{\prime} \mathrm{S}$, on both sides of the Andean Range [3,4] (Figure 1, Table S1). The southern South American freshwaters were shaped by the Andean Range and by the plateau. The Andes runs in a north-south direction, while the plateau extends towards the east. Freshwaters include many glacial deep and shallow lakes, reservoirs, and Pacific and Atlantic drainage rivers. 


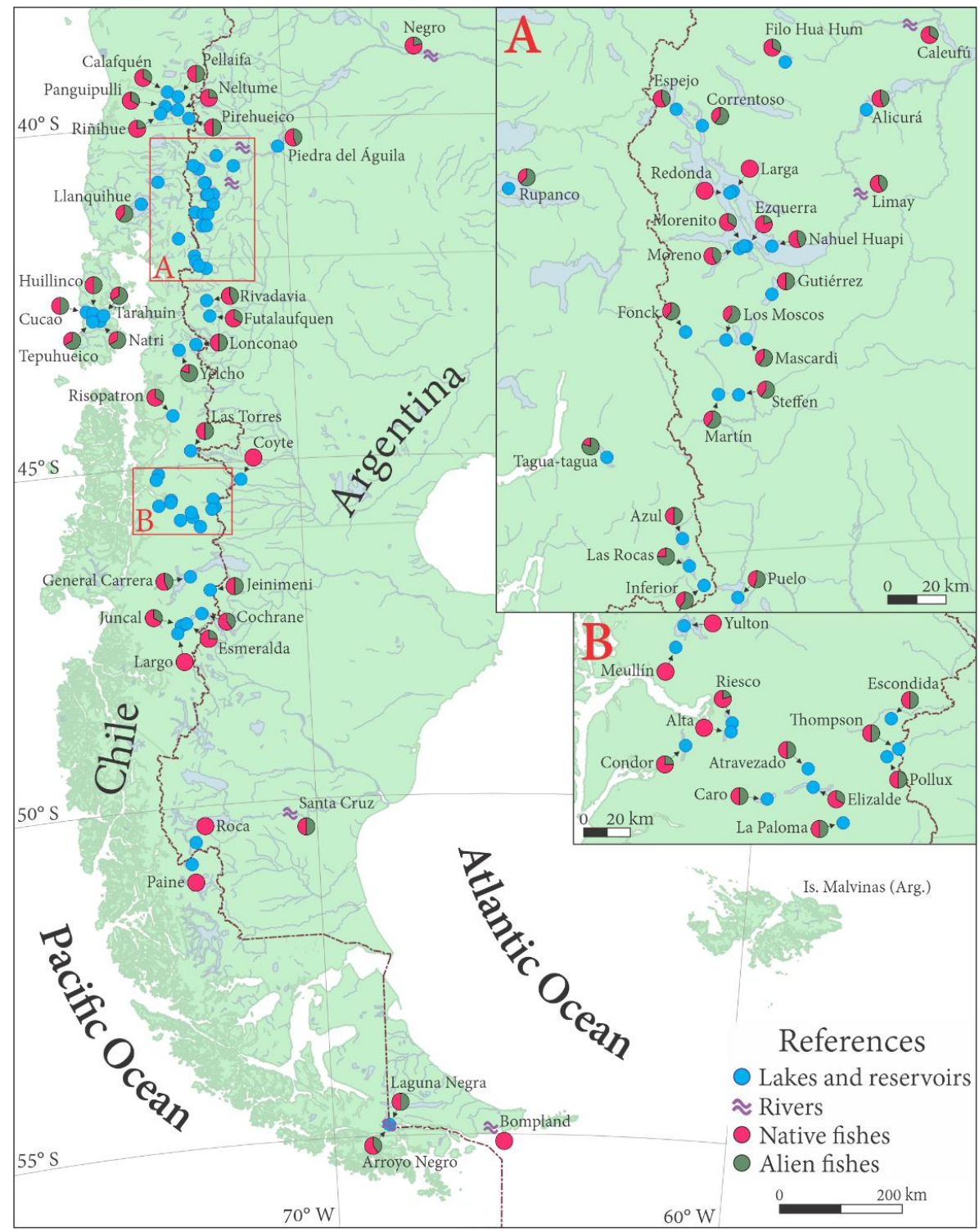

Figure 1. Lakes, reservoirs and rivers with the presence of galaxiids and alien fishes. Focus is on the Nahuel Huapi National Park (A, Argentina) and Aysén Region (B, Chile). The pie charts indicate the proportion of native and alien fishes.

Early references about Patagonian fish fauna [5] clearly recognized "Primary and secondary fishes: Trichomycteridae and other catfishes, Characidae, Poeciliidae" as having a South American origin or having entered South America from other land areas, and "Peripheral fishes: Atherinidae, Serranidae, Galaxiidae, Aplochitonidae, Geotriinae" that colonized fresh waters from marine habitats [6]. Today, this unique fish fauna comprises 29 fish species: neotropical siluriforms and characids, galaxiids, local oceanic families (percichthyids, atherinopsids and mugilids), two South American lampreys, a few species of non-native salmonids, poecilids and one cyprinid [6,7].

Previous revisions $[3,5,8]$ have established a solid baseline for the study of South American galaxiids and an enormous amount of information has been produced since then. Among South American fishes, the Galaxiidae has some distinctive characteristics; it shares a common ancestry with Gondwanan temperate fish fauna $[9,10]$, it played a major role in the post-glacial colonization of Andean lakes and streams [11-13]), and it now contributes key species to the food webs [14-16]. Moreover, as well as being the world's southernmost native freshwater fishes [17], galaxiid species occupy an enormous latitudinal gradient and show a varied range of different life history patterns $[18,19]$, 
presenting a unique opportunity for the study of local adaptation. Even before ichthyologists in the past began to understand Patagonian freshwater ecosystems, the introduction of salmonid species [20] created a new framework, which even today is still in constant change due to a number of anthropic actions. In this new paradigm, galaxiids have remained as the main forage fishes for native and exotic predators. In this scenario, the present work reviews information on the distribution, physiology and life histories of galaxiids in South America, including the variation in life history characters of their different populations.

\section{Taxonomical Update}

New information on the South American Galaxiidae [3] Aplochiton marinus Eigenmann, Aplochiton taeniatus Jenyns, Aplochiton zebra Jenyns, Brachygalaxias bullocki (Regan), Brachygalaxias gothei Busse, Galaxias globiceps Eigenmann, Galaxias maculatus (Jenyns) and Galaxias platei (Steindachner) is limited to (a) the taxonomic resurrection of A. marinus [21] and (b) genetic evidence that has allocated landlocked G. platei [22] far from G. maculatus. In agreement with the particular biological traits of G. platei [3] and depending on the different authors, genetic results placed G. platei close to the mostly landlocked Neochana species [9] and two landlocked New Zealand Galaxiidae: Galaxias sp. and Galaxias gollumoides McDowall \& Chadderton [23].

In the same way, the genetic estimation of divergence times indicates the historical presence of G. platei in South America not just before the rise of the Andes mountains, in Miocene [9], but even in the Oligocene, before the detachment of Australia and South America [9,23]. Further work is required to properly address the position of G. platei within Galaxiidae [6], including an ecomorphological and ecophysiological comparison with Neochana species.

\section{Changes in Distribution}

Zoogeographic Integrity Coefficient (ZIC) data has shown that Patagonian rivers currently show a lower ZIC than lakes [17]. The negative effects of non-native fish species have caused a reduction of the distribution ranges of Galaxiidae. Furthermore, the magnitude of these effects varies significantly with latitude, altitude and water temperature. Particularly, the non-native Gambusia causes the most severe effects in warm-water systems. Furthermore, warmer northern and coastal systems, as well as high-altitude cold-water systems, seem to offer temperature refugia for native fish that protect them from salmonids [24].

Aplochiton taeniatus, see Table S2 for the recent southernmost locality [25] and B. bullocki suffered $8-17 \%$ reductions of distributional ranges, and they have disappeared from areas of high population densities, urban growth and economic activity at latitudes $36^{\circ} \mathrm{S}$ to $41^{\circ} \mathrm{S}$ [24].

In the recent past, Galaxias platei was one of the most widespread native species [17]. Their distribution has increased considerably, but this may be due to a "better sampling effect". As an adult, G. platei is captured almost exclusively in the benthic habitat at $>30 \mathrm{~m}$ depth, below the thermocline and the euphotic zone [26]. The absence of adult G. platei in the littoral zone could be caused by the predation pressure posed by native Percichthys trucha (Cuvier \& Valenciennes) and introduced salmonids [26,27]. This is in contrast with the situation of juvenile G. platei, closely resembling G. maculatus and present in shallow littoral areas [28].

Stream records with significant captures of G. maculatus seldom occur nowadays [18]; in Chile in particular, the latitudinal range of G. maculatus has diminished by $26 \%$, mainly in the northern part of the range. Within the same basin, native galaxiids remain abundant where exotic salmonids are scarce. Galaxias maculatus has apparently been replaced by the exotic poeciliids Gambusia spp. in northern basins. High-elevation waters are still dominated by G. platei, whereas at intermediate elevations rivers are now dominated by introduced salmonids. Galaxias maculatus is also severely impacted by river fragmentation due to hydropower development in the Andean rivers of Central Chile $\left(33^{\circ} \mathrm{S}\right.$ to $38^{\circ}$ S) [29]. In highly fragmented rivers (Rapel and Maule rivers), where the species was reported up to 2010 [24], it is currently absent. Furthermore, it shows a very low abundance in the highly 
fragmented Biobío River, where G. maculatus individuals most probably come from a non-migratory population [30]. On the other hand, G. maculatus is still present in two river networks characterized by a low or null level of fragmentation (Itata and Imperial). Populations from the Imperial River network are reported to be diadromous [31].

\section{Biological Traits and Environmental Constraints}

\subsection{Feeding}

Knowledge of the feeding patterns of South American galaxiids is still fragmentary. Aplochiton zebra is an invertebrate predator [32] whose feeding habits have shown a shift from zooplankton to littoral macroinvertebrates [33]. An increase in the prey size with an increasing fish size was noted, and piscivory of individuals greater than $115 \mathrm{~mm}$ SL (Lake Puelo, Table S1) broadens the trophic preferences of A. zebra [34]. A diet overlap between A. zebra and A. taeniatus, but with differences in diet between lakes, was reported in Chilean Patagonia [35]. The presence of invasive trout significantly affected A. zebra and A. taeniatus, and caused a reduction in the consumption of adult Diptera, through changes in the feeding behavior. Furthermore, these dietary changes in the presence of invasive trout caused a reduction in the trophic position of both Aplochiton species [35].

Larval feeding of G. maculatus is based on zooplankton, while juvenile and adult feeding is based on littoral prey [36-38]. Furthermore, G. maculatus exhibits a complex trade-off between feeding and predation avoidance during the larval period that affects its phenotype. The number of food categories and number of prey ingested by G. maculatus larvae were strongly related with the zooplankton density in Patagonian oligotrophic lakes (Morenito, Ezquerra, Moreno West, Moreno East and Gutiérrez lakes, Table S1). Furthermore, the growth rate of larvae depended on the zooplankton densities and water temperature [39].

Galaxias platei is a benthic carnivore that as an adult feeds mostly on amphipods, chironomid larvae, fishes, mollusks, hirudinids, insect larvae and terrestrial insects. It exhibits cannibalistic habits and size variation in dietary composition $[40,41]$. As the $G$. platei body size increased, their proportion of littoral carbon increased, due to increased littoral feeding, in several lakes. It has been shown that the presence of invasive trout leads to the slower ontogenetic scaling of G. platei juveniles and the expansion of their trophic niche toward allochthonous prey [42]. Furthermore, a reciprocal relationship of the trophic height of large G. platei with large Salmo trutta was shown, whereby increasing densities of one caused a significant decline (shift equivalent to one trophic level) of the other [43].

\subsection{Physiological Ecology}

The largest individuals of G. maculatus were found at the southernmost limits of its distribution $\left(54^{\circ} \mathrm{S}\right)$, locations with fewest daylight hours and the lowest temperatures [44,45]. Furthermore, for individuals collected from the population inhabiting this location, the same levels of food consumption were observed during both most energy-demanding seasons (summer and winter). However, the allocation of energy differed between seasons: a higher proportion of energy was allocated to reproduction and somatic growth in summer, whereas activity support was the main energy expenditure in winter [44]. Contrary to what was expected due to low temperatures, individuals forming this population would not have lower energy demands in winter. Furthermore, no change in the metabolic rate or the postprandial increase in oxygen consumption (SDA) was observed, but there was an absence of growth in length, mass and muscle, and the depletion of energy reserves, which were allocated to fuel the metabolic costs of winter [44,46]. In addition, interestingly, the exposition of G. maculatus to a range of salinities did not affect its oxygen consumption [47]. It did, however, affect their nitrogen excretion, suggesting a switch in the substrate use [47]. Therefore, G. maculatus seems to have the capacity to sustain its metabolic rate in a broad range of environmental conditions, and it is able to adjust its metabolism and obtain energy from somatic reserves when needed. 
The metabolic activity of G. maculatus starts to increase after sunrise and reaches the highest levels between noon and sunset. It feeds mostly in the afternoon and until several hours after dusk. As such, G. maculatus occupies the littoral zone during the day, leaves the zone after dusk and returns at dawn. Galaxias maculatus commonly preys on littoral prey species, but pelagic prey are also present and preyed upon by smaller individuals $(<50 \mathrm{~mm})$ during twilight and night hours. During feeding outside of the littoral zone, G. maculatus runs a high predation risk. This risk is amended by the protection of a low light intensity. These diel movement of $G$. maculatus create a flow of energy and matter between habitats that may have significant effects on the entire food web and energy dynamics of the lake [48]. The oxygen consumption assessment of post-larval G. maculatus at a range of thermal conditions $\left(5-21^{\circ} \mathrm{C}\right)$ and fish body sizes $(0.1 \mathrm{~g}$ to $>1.5 \mathrm{~g})$ showed that specific respiration rates declined as a power function of the body mass and increased exponentially with the temperature [49]. The absence of hemoglobin in the metamorphic larvae (whitebait) of G. maculatus should be noted, and also the presence of a serum green pigment [50].

Climate change also currently poses a major threat to the native biodiversity [51], and its effects can be noted earlier at high southern latitudes compared to lower latitudes [52]. The thermal tolerance and preference of juvenile G. platei and diadromous G. maculatus were analyzed at the edge of their southern range, Tierra del Fuego, across their entire thermal acclimation range (diadromous G. maculatus: 0.5 to $29.8^{\circ} \mathrm{C}$; G. platei: 0.5 to $29.5^{\circ} \mathrm{C}$ ) [53,54]. The results indicate that $\mathrm{G}$. platei and diadromous G. maculatus (in freshwater) have broad acclimation and thermal tolerance ranges. The relationships between the Critical Thermal Maximum (Ctmax) or Critical Thermal Minimum (CTmin) and the acclimation temperatures indicate that, in comparison with G. platei, diadromous G. maculatus gains more heat and cold tolerance for every Celsius degree of increase in their acclimation temperature (Figure 2). Both species exhibit intermediate to large thermal tolerancepolygons, centrally positioned, indicating their eurythermal character. The moderately large tolerances, which are independent of a previous thermal acclimation history, enable these species to be active across a considerable temperature range, having in addition a moderate ability to acquire an additional heat/cold tolerance through acclimation. The larger upper acclimation-dependent zones also indicate that acclimation plays a major role in high rather than in low thermal tolerance. However, these fishes have high levels of cold tolerance (Figure 2). Tolerance to low temperature is a distinctive trait of G. platei and diadromous G. maculatus, with CTmin values below $0{ }^{\circ} \mathrm{C}$, which allows them to survive in waters that are ice-covered. Not surprisingly, they are two of the few native freshwater species found in Tierra del Fuego, where small lakes freeze in winter and/or the water temperature remains just above $0{ }^{\circ} \mathrm{C}[7,54]$.

a

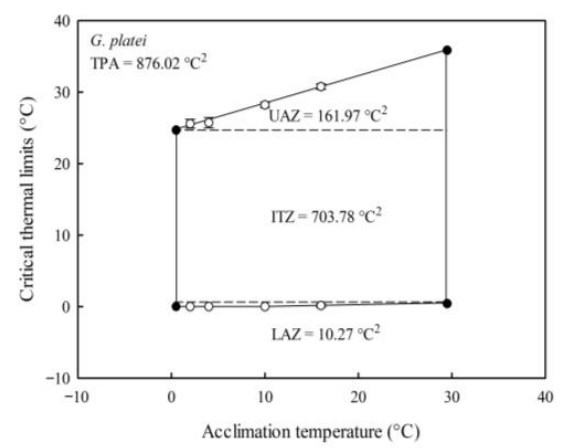

b

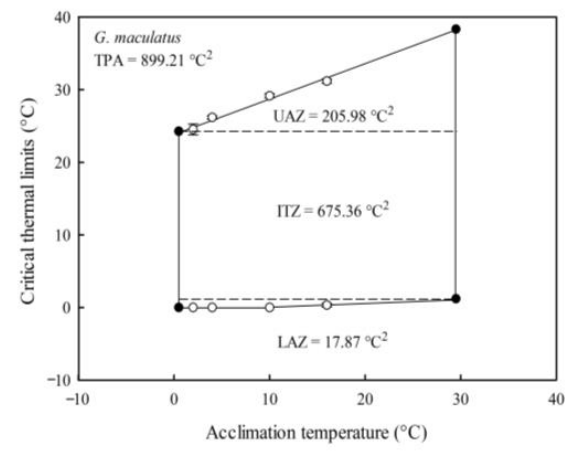

Figure 2. Thermal tolerance polygons for (a) G. platei and (b) diadromous G. maculatus from Tierra del Fuego. Polygons were constructed using Critical Thermal Maximum/Critical Thermal Minimum values $(\mathrm{CTmax} / \mathrm{CTmin}$, white circles, mean $\pm \mathrm{SD}$ ) measured at four acclimation temperatures (AT, 2, 4,10 and $16^{\circ} \mathrm{C}$ ) within their total thermal acclimation range. Extreme CTmax/CTmin values (black circles), extrapolated from regression analyses of CTmax/CTmin values on AT, are indicated. The total polygonal area (TPA) is composed of the intrinsic tolerance zone (ITZ) and the upper and lower acquired tolerance zones (UAZ, LAZ). 
Within their thermal tolerance ranges, G. platei and diadromous G. maculatus prefer certain temperatures, which increase with increasing acclimation temperatures [54]. These findings reinforce the eurythermal nature of both species revealed by thermal polygons [55]. Moreover, the relationship between oxygen consumption rates and acclimation temperatures $[56,57]$ allows for an estimation of the optimum growth temperature for G. platei juveniles at between $10{ }^{\circ} \mathrm{C}$ and $16{ }^{\circ} \mathrm{C}$, suggesting that higher growth rates occur during warmer seasons in Tierra del Fuego [54]. Thus, G. platei and diadromous G. maculatus populations at the southernmost limit of their distribution are likely to be influenced by indirect consequences of climate change rather than thermal lethality (i.e., habitat degradation or changes in the trophic structure), since they inhabit environments that are largely cooler than their maximum thermal tolerance.

\subsection{Morphological Variation}

The body shape of A. zebra was related to diet as well as water transparency and predation risk in six Andean lakes. Specifically, the eye diameter and the length of the dorsal fin of smaller juveniles $(\mathrm{SL}<40 \mathrm{~mm}$ ) differed significantly among lakes. In Lake Puelo (Table S1), with a low transparency value, $A$. zebra juveniles had the largest eyes. In Lake Futalaufquen (Table S1), with high transparency values, they had the smallest eyes. In the same way, differences in the growth trajectory of the eye size were observed between an A. zebra population from Red Pond (Malvinas Islands) and continental Patagonian populations, suggesting that a high turbidity and reduced light intensity have affected the ocular development of A. zebra [58-60]. It is likely that different effects of turbidity on the feeding ability of A. zebra, G. maculatus and G. platei could be found [3,61]. In Futalaufquen, Puelo and Rivadavia lakes (Table S1), the relationship between the principal components of A. zebra morphology and diet indicates, at least in part, that variation in body shape — and particularly traits related to the swimming ability—could be explained by the diet [34].

Galaxias maculatus larvae with deeper bodies and shorter caudal peduncles were found in lakes with high densities of zooplankton and a low predation risk, whereas slender larvae with shallower bodies and longer caudal peduncles were found in lakes with low zooplankton densities and a high predation risk. Then, food availability and predation risk would influence the swimming performance of larvae through body slenderness and caudal peduncle length [39]. Morphometric differences between lacustrine and diadromous populations of G. maculatus were observed in Isla de los Estados, Bompland river, Filo Hua Hum lake, Limay river and Tierra del Fuego (Tables S1 and S2) using geometric morphometrics, multivariate and conventional techniques. The results show a complete separation between diadromous and lacustrine populations; fish from Isla de los Estados and Bompland river partially overlap, while individuals from the Limay river and Filo Hua Hum lake are completely different [62]. In southernmost Fuegian populations (Figure 1), the body shape was found to also vary in relation to the life history. Studies performed on two close G. maculatus populations in the same hydrological basin revealed that the landlocked one (Laguna Negra) exhibited bigger eyes, a shorter and more robust body, and also a lower vertebral count than the diadromous population (Arroyo Negro). The more hydrodynamic morphometry of diadromous individuals (thinner and elongated) was interpreted in the context of an environmental adaptation to a high current velocity and predation pressure [63]. Galaxias maculatus, as a visual predator, has larger eyes than other species of Galaxias $[61,64]$. Moreover, the examination of eye size in five water bodies with distinct light climates in Tierra del Fuego revealed that G. maculatus inhabiting environments with less light penetration had larger eyes, suggesting that water color (due to the concentration of humic substances) is one of the environmental modeling factors influencing eye size. Among these studied populations, the largest mouths were found in the darkest waters, i.e., Laguna Negra and Laguna Cecilia, together with the largest eyes, probably improving feeding efficiency and predator avoidance (J.H. Rojo Pers. Comm.).

Spatial patterns of phenotypic variability among G. maculatus populations were examined in a complex of four postglacial lakes in northwestern Patagonia (Nahuel Huapi, Correntoso, Redonda and Larga lakes, Table S1) which differ in size and connectivity. Individuals from two small lakes on an 
island in Nahuel Huapi lake (Table S1) were the most morphologically divergent. The population in the isolated Redonda Lake (Table S1) also exhibited meristic differences, suggesting a strong drift and environmental effects. This population has most probably been isolated after the decline in the water level of a paleolake that existed in this region circa $13.2 \mathrm{ky} \mathrm{BP} \mathrm{[65].}$

The vertebral number of G. maculatus showed significant variations in relation to the latitude and life history expressed by the fish [19]. Specifically, an increase in the vertebral count was observed with the latitude, and a similar pattern was previously described for diadromous populations [66]. All individuals in the Santa Cruz basin (except for one individual in Roca Lake, Table S1) had vertebral numbers corresponding to the range observed for diadromous populations of G. maculatus [66]. However, individuals from the mouth of the Santa Cruz river (Piedra Buena, Table S2) had higher counts than individuals at a similar latitude, pointing to a relationship between the vertebral number and the presence or absence of diadromy [19]. Thus, the vertebral count is higher in diadromous compared to landlocked Fuegian populations (Arroyo Negro, Laguna Negra, Tables S1 and S2) [63]. At the southern extreme of the species distribution (Tierra del Fuego, $54^{\circ} \mathrm{S}$ ), four size cohorts were established, $3+$ being determined as the maximum age class in the diadromous population from Arroyo Negro, and 4+ for a landlocked one from Laguna Negra, which is probably the maximum estimated age for G. maculatus. The relationship between the mean TL and latitude was positive for South American populations [45].

The predator-associated morphology was observed [27] in G. platei individuals collected from nine deep Andean lakes and one shallow lake on the Patagonian plateau (Espejo, Gutiérrez, Moreno, Coyte, Fonck, Los Moscos, Martin, Mascardi, Steffen and Rivadavia, Table S1). The length of the caudal fin was negatively correlated with the incidence of piscivory in each lake. As such, G. platei individuals from lakes with high piscivory rates were characterized by relatively short caudal fins, and those from lakes with low piscivory were characterized by long caudal fins. The population from lake Espejo (Table S1), with an intermediate piscivory level, was inhabited by individuals with both long and short caudal fins. Furthermore, the morphological variation within this lake was explained by the exploitation of food resources and habitat use. Specifically, individuals with shorter tails were characterized by a high frequency of amphipods in their diet and inhabited shallow habitats. Therefore, the between-lake morphological variation was significantly influenced by differences in predation intensity, whereas the within-lake morphological variation appeared to be affected by both predation and differences in the exploitation of food resources. Moreover, a morphological variability in 23 morphometric traits was recorded in G. platei individuals collected from 20 postglacial lakes covering the latitudinal range of the species. Significant differences in body shape among populations were recorded. These differences were most strongly expressed in the shape and dimensions of the head, as well as the morphology and length of the caudal fin. Pelvic measures were negatively correlated with amphipod consumption, indicating at least partial effects of the diet on the morphology. Finally, these multiple sources of evidence indicate that morphology significantly varies across latitudes and that it is associated with the risk of predation and diet [67].

The variation in the vertebral number was assessed in G. platei specimens from 22 locations between $40^{\circ}$ and $55^{\circ}$ latitude $\mathrm{S}$. The mean vertebral number followed Jordan's rule and was characterized by an increase towards higher latitudes. Temperature variation explained a large proportion of variations of the vertebral number of G. platei, as expected due to its high latitudinal and altitudinal geographic variation. Specifically, the mean winter air temperature was negatively correlated with the mean vertebral number. The increment in the vertebral number seems to occur primarily in the pre-pelvic region of the trunk and in the caudal region, but not in the segment between the pelvic-fin insertion and the origin of the anal fin, and it is expected to have significant consequences for hydrodynamics and the swimming performance [68]. 


\subsection{Reproduction and Life History Patterns}

Based on the analyses of Sr: Ca ratios in otoliths, a diadromous life history was suggested for populations of A. taeniatus, A. marinus and G. maculatus. Lifetime residency in freshwater was suggested for A. zebra and G. platei populations [22]; however, A. zebra individuals were also captured in the Beagle Channel (Lattuca, pers. com.).

The spawning and development of landlocked A. zebra in Argentine Patagonia were analyzed through the presence of eggs, gonadal development, otolith daily increments and length frequencies. Among Patagonian galaxiids, an intermediate size and age at first maturity is shown by A. zebra, together with vitellogenic oocytes covered with short chorionic filaments. Furthermore, larger free embryos were found in A. zebra than in G. maculatus and G. platei [69].

Galaxias maculatus presents both diadromous and landlocked populations [22,30,31]. Both were reported in the eastern sites of the Andes in river basins of southern Chile [31]. The majority of Andean rivers below $41^{\circ} \mathrm{S}$ characterized by predictable seasonal flow regimes and productive floodplains (Biobío, Valdivia, Bueno and Petrohué) were dominated by freshwater resident populations, and diadromous populations were found only in lower reaches and estuaries [31]. This pattern changed at higher latitudes, and the populations inhabiting Puelo, Aysén, Cisnes and Baker river basins were characterized by a higher frequency of diadromous life histories [31]. This latitudinal pattern of frequency of diadromy is clearly reflected in the genetic diversity and structure of G. maculatus populations in these rivers [30]. Diadromous populations experienced a high gene flow between basins and a high genetic diversity, whereas freshwater resident populations are highly structured and differ significantly between river basins. Furthermore, in comparison with diadromous populations, freshwater resident populations in the northern river basins, as well as at the southernmost extreme of the species distribution (Tierra del Fuego), experienced a low to non-existent gene flow and were characterized by lower effective population sizes [30,63].

The facultative diadromy was also documented for G. maculatus in the Santa Cruz River basin, while no evidence of diadromy was found in individuals from the Negro River basin (Table S2) [19]. Only some individuals of G. maculatus populations found at the mouth of Santa Cruz River (that discharges to the Atlantic Ocean) were characterized by high Sr concentrations in the otolith. It was concluded that different life histories can be found in sympatry, and no genetic structuring between individuals from the sampling site was detected, suggesting that similar genotypes have different phenotypes. In agreement with other results $[18,70,71]$, the estimates of recent migration rates between genetic clusters suggest that migration occurs predominantly in an upstream direction (larvae), both in the Negro river and in Santa Cruz river basins. The high genetic diversity observed among Piedra Buena (Table S2) individuals suggests that this is a large population, and the possibility of a genetic exchange with other diadromous populations should not be discarded [72]; for example, populations in Tierra del Fuego $[63,73,74]$ and along the Chilean coast [13].

On Tierra del Fuego island, G. maculatus populations were characterized by an extended reproductive season, with differences in the timing and duration of spawning compared to other populations of continental Patagonia, New Zealand and Australia [18,70,71,73,75-79]. Females here reach larger sizes compared to those of other South American populations. In the diadromous Negro stream population, individual fecundity is lower than in other populations, but egg production increases through individual repetitive spawning during the protracted spawning period (from October to February). Mature males abound in the spawning grounds during the reproductive season. The size of mature females decreases throughout the breeding season. There is an extremely high investment in reproduction for both sexes, with a maximum gonadosomatic index of about $35 \%$. At the beginning of the reproductive season, the maximum hepatosomatic index is reached by females and the minimum by males, suggesting differences in the allocation of energy reserves during sexual maturation. In the Negro stream diadromous population, the 1+ age class was the most numerous and contributed most to the population's reproduction for both sexes [45], while the 2+ class did the same for the landlocked 
population from Laguna Negra. Variation in the peri-visceral fat index suggests that fat reserves were used to survive winter $[46,73,74]$.

Diadromous populations of G. maculatus exhibit an upstream migration of metamorphic larvae from the sea to freshwater habitats, but an upstream migration of those that are landlocked has also been reported in one particular riverine population that presents an upstream migration from the Piedra del Águila Reservoir to Caleufú River (Tables S1 and S2) at the larva-juvenile transition. There, the spawning season, from September to November, and the arrival of shoals of metamorphic larvae and juveniles to adult habitats, from February to April, coincide with lacustrine landlocked populations, but not with diadromous populations. Furthermore, the growth rate and age at migration (147 \pm 22.6 days) of this population were similar to other landlocked and diadromous populations. A 20-fold increase in the fish density and overlapping of the two cohorts was observed at the arrival of these shoals of G. maculatus. The morphology and vertebrae numbers were similar in riverine and reservoir adults [18].

The great plasticity of G. maculatus life history could be the key to explaining the wide distribution of this species in the Southern Hemisphere [71]. Likewise, this juvenile potamodromous behavior in a landlocked population will provide a new perspective for the analysis of this species' dispersion in continental waters [18]. In this way, the spatial patterns of the genetic and phenotypic variability observed in G. maculatus populations in a complex of four postglacial lakes in northwestern Patagonia, which differ in size and the level of connectivity between them, indicated restricted genetic structuring within large lakes, probably because G. maculatus larvae migrate to the limnetic zone of Patagonian lakes and may exert a homogenizing effect on the gene flow within lakes [65].

The reproductive characteristics of G. platei were studied in Lake Moreno (Table S1). Histological analyses of G. platei ovaries have shown a synchronous oocyte development typical of a group-synchronous spawner. The diameter of mature oocytes ranged from 1031 to $1419 \mu \mathrm{m}$. Based on the gonadosomatic index, it was shown that annual spawning occurs during austral autumn (between April and June) and is strongly associated with a deeper strata water temperature (below $30 \mathrm{~m}$ ) and not with the photo-period. Female G. platei acquire a mature sexuality at a standard length of approximately $105 \mathrm{~mm}$, whereas males at a length of approximately $177 \mathrm{~mm}$. The delayed maturity that results in a higher fecundity, as well as a maximum body size and longevity, indicate that G. platei is more specialized in terms of its life history compared to G. maculatus. These specialized features are related to the stable environment inhabited by G. platei, and indicate the vulnerability of this species to more instable environments. Such a higher instability is expected in Patagonian lakes dominated by salmonids [74]. In Thompson Lake, a small, high-elevation lake located in the Aysen River basin (Chile), G. platei occurs essentially in isolation. In the absence of other native and introduced fishes, G. platei is long-lived and reaches a maximum age of 18 years and a maximum total length of $348 \mathrm{~mm}$ [43]. Comparing life histories within Galaxias, G. platei invests more energy in growth while delaying sexual maturity. Galaxias platei is the largest and longest-lived species of the Patagonian Galaxiidae species $[41,74]$. In Thompson Lake, the ecology of G. platei is dominated by a strong ontogenetic niche shift. Small, young G. platei inhabit the shallow littoral zone, feed on macroinvertebrates and grow rapidly. As they grow to a larger size and become reproductively mature, individuals shift to the deeper benthic habitat, their diet shifts towards piscivory and the growth rates decline. As a result, large and small G. platei occupy two distinct niches in this system, and they interact primarily as predator and prey [43].

\subsection{Predation Risk}

Reduced abundances and the loss of different prey species due to predation by rainbow trout Oncorhynchus mykiss (Walbaum) in Lake Moreno (Table S1) were estimated through a bioenergetic model with input data on distribution, thermal experience, growth and seasonal diet. Pelagic galaxiid larvae and benthic juvenile and adult G. maculatus were the most important components of the trout diet. Bioenergetic simulations indicated that $20 \%$ of the food consumed by rainbow trout consisted 
of galaxiid larvae and that $16 \%$ consisted of adult G. maculatus [80]. The triggering of anti-predator responses in G. maculatus was experimentally studied, with visual and chemical cues of the predator $O$. mykiss, and a reduction of the swimming activity and changes in the respiratory rate of G. maculatus were found [81].

\section{Climate Change, Invasions and Translocations}

Temperature [6,82] and the concept of thermal niche [83] are at the very basis of the ongoing interplay between the confluence of different fish groups and the environment in Patagonia. During the period 1961-2018, the temperature increase in Patagonia (annual mean temperature) reached up to $1.5{ }^{\circ} \mathrm{C}$ [84]. Models (base CMIP5) for the 21st century predict an increase of the mean temperature, greater in the far future (RCP8.5 scenery, $1{ }^{\circ} \mathrm{C}$ ) than in the near future ( $\mathrm{RCP} 4.5$ scenery, $0.5{ }^{\circ} \mathrm{C}$ ). Regarding rainfall, the RCP8.5 scenery projects a decrease (10\% to $20 \%)$ in northwestern and central Patagonia (SRES A2 and B2 sceneries). The projected impacts include the replacement of species and changes in distribution [85].

Simultaneously with climate change [17], two situations can be summarized to be occurring in the region: (a) The southward expansion of species limited by low temperatures: characins (Astyanax eigenmanniorum Cope, Cheirodon interruptus (Jenyns), Oligosarcus jenynsii Günther), catfishes (Corydoras paleatus (Jenyns)), cyprinodontiforms (Cnesterodon decemmaculatus (Jenyns), Jenynsia multidentata (Jenyns)), the atherinopsid Odontesthes bonariensis (Valenciennes) and the exotic Cyprinus carpio Linnaeus; and (b) north extirpations of galaxiids (G. maculatus and G. platei) and exotic Salmonidae, both groups limited in their northward distribution by high temperatures [17].

Northern Hemisphere freshwater salmonids have been introduced in many river basins around the world, and several species of salmonids were introduced in Patagonia during the 20th century. These introductions were aimed to increase fish diversity and generate sport fishery opportunities $[20,86]$. Established salmonid populations resulted in the partial displacement of several native Patagonian galaxiids species from their historical distribution ranges due to negative interactions such as competition and predation $[33,87]$. Furthermore, escaped farmed rainbow trout in reservoirs have been shown to negatively affect native populations [88-90].

Recently, C. carpio, formerly introduced in the lower Colorado river in the mid-1980s, has invaded the Negro river (Table S2) [7]. The distribution of C. carpio in North and South America was shown to be strongly related to the annual maximum air temperature and the concentration of chlorophyll-a [91]. These two variables were also excellent predictors of the presence of $C$. carpio in Argentina. Lakes and reservoirs that were invaded by C. carpio have a mean annual air temperature higher than $10^{\circ} \mathrm{C}$. Present capture data for the Negro River indicate the presence of $C$. carpio in locations with water temperatures below the preference and optimum growth range of this species. However, a warming climate is expected to give advantage to this successful invader, and it may spread further along the Limay river, in the upper Negro basin [7]. Translocations have also contributed to extirpations of native populations, as is the case with the native atherinopsid $O$. hatcheri [6].

A population decline and the extirpations of galaxiids were observed in Northern Patagonia. Galaxias maculatus was found to be at low abundance in the Negro River, the northernmost limit of its distribution in Argentina [92], and extirpations have already been observed [24] in the northernmost populations of the species in Chile [3]. In the same area, two other galaxiid species, B. gothei and G. globiceps, seem to be completely extinct [8,24], and though captures performed between 1930 and 1945 signalized the presence of $A$. zebra in the upper Negro river basin, no other record was taken since 1945 [3].

\section{Conclusions}

Knowledge of South American galaxiids has improved markedly (Table S3). Biological data and the distinct life-history patterns are interpreted as adaptations to variable environments. The broad world distribution of Galaxiidae species in the Southern Hemisphere is understood in the context of 
its great life-history plasticity [18]. However, new challenges (Table S4) arise due to climate change, biological invasions, damming, aquaculture and contamination. The thermal preference and tolerance values of A. zebra, G. maculatus and G. platei [92] suggest that South American galaxiids are limited to the north by high temperatures. In fact, some of the northernmost populations of G. maculatus [3] are considered extirpated [24] or in decline [93]. Biological invasions are not limited to the introduction of salmonids [94]: several Neotropical species [6,17] and the common carp Cyprinus carpio [7] have invaded the northernmost distribution area of Patagonian galaxiids with consequences that have not yet been studied. Damming and the creation of anthropogenic [94], but also natural, reservoirs-e.g., dams created by the Canadian beaver Castor canadensis [95] — have provided new conditions for galaxiid populations $[18,96]$ and also a place for salmonid cage aquaculture. Farmed rainbow trout escapes have been recorded in the Alicura reservoir (Table S1) [88], with consequences for habitat use and food webs $[89,90]$. Contamination is a new issue for Patagonian waters, and recent results [97-99] have sounded an alarm. In this changing environment with increasing anthropic action, the future of South American galaxiids should be carefully considered as a legacy of the old Gondwana, which arrived in our hands after surviving an epic journey of apocalyptic geological changes [6,100-102] and now constitutes a wonderful, distinctive trait of the freshwaters of southern South America.

Supplementary Materials: The following are available online at http://www.mdpi.com/1424-2818/12/5/178/s1, Table S1: Lakes and reservoirs with presence of galaxiids. Basin, latitude, and fish species are indicated. Detailed positions are shown in Figure 1, Table S2: Rivers and streams mentioned in the text. Fish species present and corresponding river basins are indicated, Table S3: Summary of the key, distinguishing attributes (Taxonomy, Changes in distribution, Feeding and thermal tolerance, Morphological variation, Vertebral number, Life history) of the galaxiid species in South America; Aplochiton marinus, Aplochiton taeniatus, Aplochiton zebra, Brachygalaxias bullocki, Brachygalaxias gothei, Galaxias globiceps, Galaxias maculatus and Galaxias platei, Table S4: The key documented threats to the galaxiid species. The effects of threats (exotic fishes, warming, river fragmentation and human activities) on the galaxiid species (Aplochiton marinus, Aplochiton taeniatus, Aplochiton zebra, Brachygalaxias bullocki, Brachygalaxias gothei, Galaxias globiceps, Galaxias maculatus and Galaxias platei) are indicated.

Author Contributions: Conceptualization, C.C.B., E.H., J.H.R.; K.G., M.E.B., M.E.L. and V.E.C.; software, J.R.; resources, C.C.B., E.H., J.H.R.; K.G., M.E.B., M.E.L. and V.E.C.; writing-original draft preparation, V.E.C.; writing-review and editing, C.C.B., E.H., J.H.R.; K.G., M.E.B., M.E.L. and V.E.C.; supervision, V.E.C. All authors have read and agreed to the published version of the manuscript.

Funding: This research was funded by Consejo Nacional de Investigaciones Científicas y Técnicas (Argentina), grant number 11220170100081 CO, Fondo para la Investigación Científica y Tecnológica (Argentina), grant numbers PID 4563 (UTN), PICT $2014^{\circ}$ N 1804, PICT 2017 N 0664, PICT 2017 ${ }^{\circ}$ 3845, and Fondo Nacional de Desarrollo Científico y Tecnológico (Chile), grant numbers 11180545 and 1190647.

Conflicts of Interest: The authors declare no conflict of interest.

\section{References}

1. Cussac, V.E.; Habit, E.; Ciancio, J.; Battini, M.A.; Riva Rossi, C.; Barriga, J.P.; Baigún, C.; Crichigno, S. Freshwater fishes of Patagonia: Conservation and fisheries. J. Fish Biol. 2016, 89, 1068-1097. [CrossRef]

2. Dyer, B. Systematic review and biogeography of the freshwater fishes of Chile. Estud. Oceanol. 2000, 19, 77-98.

3. Cussac, V.; Ortubay, S.; Iglesias, G.; Milano, D.; Lattuca, M.; Barriga, J.; Battini, M.; Gross, M. The distribution of South American galaxiid fishes: The role of biological traits and post glacial history. J. Biogeogr. 2004, 31, 103-122. [CrossRef]

4. Habit, E.; Gonzalez, J.; Ruzzante, D.E.; Walde, S.J. Native and introduced fish species richness in Chilean Patagonian lakes: Inferences on invasion mechanisms using salmonid-free lakes. Divers. Distrib. 2012, 18, 1153-1165. [CrossRef]

5. McDowall, R.M. The galaxiid fishes of South America. Zool. J. Linn. Soc. 1971, 50, 33-74. [CrossRef]

6. Becker, L.A.; Crichigno, S.A.; Cussac, V.E. Climate change impacts on freshwater fishes: A Patagonian perspective. Hydrobiologia 2018, 816, 21-38. [CrossRef]

7. Crichigno, S.; Cordero, P.; Blasetti, G.; Cussac, V. Dispersion of the invasive common carp Cyprinus carpio in Southern South America: Changes and expectations, westward and southward. J. Fish Biol. 2016, 89, 403-416. [CrossRef] 
8. Habit, E.; Dyer, B.; Vila, I. Estado de conocimiento de los peces dulceacuícolas de Chile. Gayana 2006, 70 , 100-112. [CrossRef]

9. Burridge, C.P.; McDowall, R.M.; Craw, D.; Wilson, M.V.H.; Waters, J.M. Marine dispersal as a prerequisite for Gondwanan vicariance among elements of the galaxiid fish fauna. J. Biogeogr. 2012, 39, 306-321. [CrossRef]

10. Betancur, R.; Wiley, E.O.; Arratia, G.; Acero, A.; Bailly, N.; Miya, M.; Lecointre, G.; Ortí, G. Phylogenetic classification of bony fishes. BMC Evol. Biol. 2017, 17, 162. [CrossRef]

11. Ruzzante, D.E.; Walde, S.J.; Gosse, J.C.; Cussac, V.E.; Habit, E.; Zemlak, T.S.; Adams, E.D.M. Climate control on ancestral population dynamics: Insight from patagonian fish phylogeography. Mol. Ecol. 2008, 17, 2234-2244. [CrossRef] [PubMed]

12. Zemlak, T.S.; Habit, E.M.; Walde, S.J.; Battini, M.A.; Adams, E.D.M.; Ruzzante, D.E. Across the southern Andes on fin: Glacial refugia, drainage reversals and a secondary contact zone revealed by the phylogeographical signal of Galaxias platei in Patagonia. Mol. Ecol. 2008, 17, 5049-5061. [CrossRef] [PubMed]

13. Zemlak, T.S.; Habit, E.M.; Walde, S.J.; Carrea, C.; Ruzzante, D.E. Surviving historical Patagonian landscapes and climate: Molecular insights from Galaxias maculatus. BMC Evol. Biol. 2010, 10, 67. [CrossRef] [PubMed]

14. Macchi, P.J.; Pascual, M.A.; Vigliano, P.H. Differential piscivory of the native Percichthys trucha and exotic salmonids upon the native forage fish Galaxias maculatus in Patagonian Andean lakes. Limnologica 2007, 37, 76-87. [CrossRef]

15. Juncos, R.; Beauchamp, D.A.; Vigliano, P.H. Modeling prey consumption by native and nonnative piscivorous fishes: Implications for competition and impacts on shared prey in an ultraoligotrophic lake in Patagonia. Trans. Am. Fish. Soc. 2013, 142, 268-281. [CrossRef]

16. Juncos, R.; Milano, D.; Macchi, P.J.; Vigliano, P.H. Niche segregation facilitates coexistence between native and introduced fishes in a deep Patagonian lake. Hydrobiologia 2015, 747, 53-67. [CrossRef]

17. Aigo, J.; Cussac, V.; Peris, S.; Ortubay, S.; Gómez, S.; López, H.; Gross, M.; Barriga, J.; Battini, M. Distribution of introduced and native fish in Patagonia (Argentina): Patterns and changes in fish assemblages. Rev. Fish Biol. Fish. 2008, 18, 387-408. [CrossRef]

18. Barriga, J.P.; Battini, M.A.; Cussac, V.E. Annual dynamics variation of landlocked Galaxias maculatus (Jenyns 1842) population in a northern Patagonia river: Occurrence of juvenile upstream migration. J. Appl. Ichthyol. 2007, 23, 128-135. [CrossRef]

19. Carrea, C.; Cussac, V.E.; Ruzzante, D.E. Genetic and phenotypic variation among Galaxias maculatus populations reflects contrasting landscape effects between northern and southern Patagonia. Freshw. Biol. 2013, 58, 36-49. [CrossRef]

20. Macchi, P.J.; Vigliano, P.H.; Pascual, M.A.; Alonso, M.; Denegri, M.A.; Milano, D.; Garcia Asorey, M.; Lippolt, G. Historical policy goals for fish management in northern continental Patagonia Argentina: A structuring force of actual fish assemblages? Am. Fish. Soc. Symp. 2008, 49, 331-348.

21. Alò, D.; Correa, C.; Arias, C.; Cárdenas, L. Diversity of Aplochiton fishes (Galaxiidea) and the taxonomic resurrection of A. marinus. PLoS ONE 2013, 8, e71577. [CrossRef] [PubMed]

22. Alò, D.; Correa, C.; Samaniego, H.; Krabbenhoft, C.A.; Turner, T.F. Otolith microchemistry and diadromy in Patagonian river fishes. PeerJ 2019, 7, e6149. [CrossRef] [PubMed]

23. Vera-Escalona, I.; Habit, E.; Ruzzante, D.E. Echoes of a distant time: Effects of historical processes on contemporary genetic patterns in Galaxias platei in Patagonia. Mol. Ecol. 2015, 24, 4112-4128. [CrossRef] [PubMed]

24. Habit, E.; Piedra, P.; Ruzzante, D.; Walde, S.; Belk, M.; Cussac, V.; Gonzalez, J.; Colin, N. Changes in the distribution of native fishes in response to introduced species and other anthropogenic effects. Glob. Ecol. Biogeogr. 2010, 19, 697-710. [CrossRef]

25. Maldonado-Márquez, A.; Contador, T.; Rendoll-Cárcamo, J.; Moore, S.; Pérez-Troncoso, C.; Gomez-Uchida, D.; Harrod, C. Southernmost distribution limit for endangered Peladillas (Aplochiton taeniatus) and non-native coho salmon (Oncorhynchus kisutch) coexisting within the Cape Horn biosphere reserve, Chile. J. Fish Biol. 2020, 1-6. [CrossRef] [PubMed]

26. Milano, D.; Vigliano, P.H. Nuevos registros de Galaxias platei Steindachner, 1898 en lagos andinos-patagónicos (Teleostei: Osmeriformes: Galaxiidade). Neotropica 1997, 43, 109-111.

27. Milano, D.; Cussac, V.E.; Macchi, P.J.; Ruzzante, D.E.; Alonso, M.F.; Vigliano, P.H.; Denegri, M.A. Predator associated morphology in Galaxias platei in Patagonian lakes. J. Fish Biol. 2002, 61, 138-156. [CrossRef] 
28. Correa, C.; Hendry, A. Invasive salmonids and lake order interact in the decline of puye grande Galaxias platei in western Patagonia lakes. Ecol. Appl. 2012, 22, 828-842. [CrossRef]

29. Díaz, G. Revealing the Effects of Loss of Longitudinal Connectivity on Freshwater Fish in Andean River Networks. Ph.D. Thesis, University of Concepción, Concepción, Chile, 2019.

30. Delgado, M.L.; Górski, K.; Habit, E.; Ruzzante, D.E. The effects of diadromy and its loss on genomic divergence: The case of amphidromous Galaxias maculatus populations. Mol. Ecol. 2019. [CrossRef]

31. Górski, K.; Habit, E.M.; Pingram, M.A.; Manosalva, A.J. Variation of the use of marine resources by Galaxias maculatus in large Chilean rivers. Hydrobiologia 2018, 814, 61-73. [CrossRef]

32. McDowall, R.M.; Nakaya, K. Morphological divergence in the two species of Aplochiton Jenyns (Salmoniformes: Aplochitonidae): A generalist and a specialist. Copeia 1988, 1, 233-236. [CrossRef]

33. Lattuca, M.E.; Battini, M.; Macchi, P.J. Trophic interaction among fishes in a northern Patagonian oligotrophic lake. J. Fish Biol. 2008, 72, 1306-1320. [CrossRef]

34. Lattuca, M.E.; Ortubay, S.; Battini, M.A.; Barriga, J.P.; Cussac, V.E. Presumptive environmental effects on body shape of Aplochiton zebra (Pisces, Galaxiidae) in Northern Patagonian lakes. J. Appl. Ichthyol. 2007, 23, 25-33. [CrossRef]

35. Elgueta, A.; González, J.; Ruzzante, D.E.; Walde, S.J.; Habit, E. Trophic interference by Salmo trutta on Aplochiton zebra and Aplochiton taeniatus in southern Patagonian lakes. J. Fish Biol. 2013, 82, 430-443. [CrossRef]

36. Cervellini, P.M.; Battini, M.A.; Cussac, V.E. Ontogenetic shifts in the feeding of Galaxias maculatus (Galaxiidae) and Odontesthes microlepidotus (Atherinidae). Environ. Biol. Fish. 1993, 36, 283-290. [CrossRef]

37. Modenutti, B.E.; Balseiro, E.G.; Cervellini, P.M. Effect of the selective feeding of Galaxias maculatus (Salmoniformes Galaxiidae) on zooplankton of a South Andes lake. Aquat. Sci. 1993, 55, 65-75. [CrossRef]

38. Ferriz, A. Alimentación del puyen Galaxias maculatus (Jenyns) en el río Limay, Provincia de Neuquén. Physica B 1984, 42, 29-32.

39. Barriga, J.P.; Battini, M.A.; García-Asorey, M.; Carrea, C.; Macchi, P.J.; Cussac, V.E. Intraspecific variation in growth and morphology of landlocked Galaxias maculatus during the limnetic period of its life history. Hydrobiologia 2012, 679, 27-41. [CrossRef]

40. Ferriz, R.A. Alimentación de Galaxias platei (Pisces, Galaxiidae) en siete ambientes lénticos de la provincia de Chubut, Argentina. Rev. Mus. Argentino Ciencias Nat. 2003, 5, 79-85. [CrossRef]

41. Belk, M.C.; Habit, E.; Ortiz-Sandoval, J.J.; Sobenes, C.; Combs, E.A. Ecology of Galaxias platei in a depauperate lake. Ecol. Freshw. Fish 2014, 23, 615-621. [CrossRef]

42. Ortiz-Sandoval, J.; Górski, K.; Sobenes, C.; González, J.; Manosalva, A.; Elgueta, A.; Habit, E. Invasive trout affect trophic ecology of Galaxias platei in Patagonian lakes. Hydrobiologia 2017, 790, 201-212. [CrossRef]

43. Correa, C.; Bravo, A.P.; Hendry, A.P. Reciprocal trophic niche shifts in native and invasive fish: Salmonids and galaxiids in Patagonian lakes. Freshw. Biol. 2012, 57, 1769-1781. [CrossRef]

44. Boy, C.C.; Pérez, A.F.; Tagliaferro, M.; Lattuca, M.E.; Gutiérrez, M.; Vanella, F.A. Exploring bioenergetics of diadromous Galaxias maculatus in the southernmost extreme of its distribution: Summer is not always the better season. J. Exp. Mar. Biol. Ecol. 2017, 488, 102-110. [CrossRef]

45. Rojo, J.H.; Figueroa, D.E.; Boy, C.C. Age and growth of diadromous Galaxias maculatus (Jenyns, 1842) in southernmost South America ( $\left.54^{\circ} \mathrm{S}\right)$ including contribution of age classes to reproduction. Environ. Biol. Fish. 2018, 101, 1149-1160. [CrossRef]

46. Boy, C.C.; Pérez, A.F.; Fernández, D.A.; Calvo, J.; Morriconi, E.R. Energy allocation in relation to spawning and overwintering of a diadromous puyen (Galaxias maculatus) population in the southernmost limit of the species distribution. Polar Biol. 2009, 32, 9-14. [CrossRef]

47. Urbina, M.A.; Glover, C.N. Effect of salinity on osmoregulation, metabolism and nitrogen excretion in the amphidromous fish, inanga (Galaxias maculatus). J. Exp. Mar. Biol. Ecol. 2015, 473, 7-15. [CrossRef]

48. Milano, D.; Aigo, J.C.; Macchi, P.J. Diel patterns in space use, food and metabolic activity of Galaxias maculatus (Pisces: Galaxiidae) in the littoral zone of a shallow Patagonian lake. Aquat. Ecol. 2013, 47, 277-290. [CrossRef]

49. Milano, D.; Vigliano, P.H.; Beauchamp, D.A. Effect of body size and temperature on respiration of Galaxias maculatus (Pisces: Galaxiidae). N. Z. J. Mar. Freshw. Res. 2017, 51, 295-303. [CrossRef]

50. Busse, K. On a green pigment in the blood-serum of subadult lacustrine Galaxias (Pisces; Galaxiidae). Bonn. Zool. Beitr. Bd. 1993, 44, 125-131. 
51. Heller, N.E.; Zavaleta, E.S. Biodiversity management in the face of climate change: A review of 22 years of recommendations. Biol. Conserv. 2009, 142, 14-32. [CrossRef]

52. Gille, S.T. Warming of the Southern Ocean since the 1950s. Science 2002, 295, 1275-1277. [CrossRef] [PubMed]

53. Lattuca, M.E.; Boy, C.C.; Vanella, F.A.; Barrantes, M.E.; Fernández, D.A. Thermal responses of three native fishes from estuarine areas of the Beagle Channel, and their implications for climate change. Hydrobiologia 2018, 808, 235-249. [CrossRef]

54. Barrantes, M.E.; Lattuca, M.E.; Vanella, F.A.; Fernández, D.A. Thermal ecology of Galaxias platei (Pisces, Galaxiidae) in South Patagonia: Perspectives under a climate change scenario. Hydrobiologia 2017, 802, 255-267. [CrossRef]

55. Johnson, J.A.; Kelsch, S.W. Effects of evolutionary thermal environment on temperature-preference relationships in fishes. Environ. Biol. Fish. 1998, 4, 447-458. [CrossRef]

56. Das, T.; Pal, A.K.; Chakraborty, S.K.; Manush, S.M.; Chatterjee, N.; Mukherjee, S.C. Thermal tolerance and oxygen consumption of Indian Major Carps acclimated to four temperatures. J. Therm. Biol. 2004, 29, 157-163. [CrossRef]

57. Kita, J.; Tsuchida, S.; Setoguma, T. Temperature preference and tolerance, and oxygen consumption of the marbled rockfish, Sebastiscus marmoratus. Mar. Biol. 1996, 125, 467-471. [CrossRef]

58. McDowall, R.M. Falkland Islands biogeography: Converging trajectories in the South Atlantic Ocean. J. Biogeogr. 2005, 32, 49-62. [CrossRef]

59. Pankhurst, N.W. Ocular morphology of the sweep Scorpis lineolatus and the spotty Pseudolabrus celidotus (Pisces: Teleostei) grown in low intensity light. Brain Behav. Evol. 1992, 39, 116-123. [CrossRef]

60. McDowall, R.M.; Pankhurst, N.W. Loss of negative eye-size in a population of Aplochiton zebra (Teleostei: Galaxiidae) from the Falkland Islands. N. Z. J. Zool. 2005, 32, 17-22. [CrossRef]

61. Rowe, D.K.; Dean, T.L. Effects of turbidity on the feeding ability of the juvenile migrant stage of six New Zealand freshwater fish species. N. Z. J. Mar. Freshw. Res. 1998, 32, 21-29. [CrossRef]

62. Ferriz, R.A.; Gómez, S.E. Polymorphism of lacustrine and diadromous populations of Galaxias maculatus, Argentina, South America. Bioikos 2015, 29, 19-25.

63. Rojo, J.H.; Fernández, D.A.; Figueroa, D.E.; Boy, C.C. Phenotypic and genetic differentiation between diadromous and landlocked puyen Galaxias maculatus. J. Fish Biol. 2020. [CrossRef] [PubMed]

64. McDowall, R.M. New Zealand Freshwater Fishes: A Guide and Natural History; Heinemann Reed: Auckland, Australia, 1990; 232p.

65. Carrea, C.; Barriga, J.P.; Cussac, V.E.; Ruzzante, D.E. Genetic and phenotypic differentiation among Galaxias maculatus populations in a Patagonian postglacial lake system. Biol. J. Linn. Soc. 2012, 107, 368-382. [CrossRef]

66. McDowall, R.M. Variation in vertebral number in galaxiid fishes (Teleostei: Galaxiidae): A legacy of life history, latitude and length. Environ. Biol. Fish. 2003, 66, 361-381. [CrossRef]

67. Milano, D.; Ruzzante, D.E.; Cussac, V.E.; Macchi, P.J.; Ferriz, R.A.; Barriga, J.P.; Aigo, J.C.; Lattuca, M.E.; Walde, S.J. Latitudinal and ecological correlates of morphological variation in Galaxias platei (Pisces, Galaxiidae) in Patagonia. Biol. J. Linn. Soc. 2006, 87, 69-82. [CrossRef]

68. Barriga, J.P.; Milano, D.; Cussac, V.E. Variation in vertebral number and its morphological implication in Galaxias platei. J. Fish Biol. 2013, 83, 1321-1333. [CrossRef]

69. Lattuca, M.E.; Brown, D.; Castiñeira, L.; Renzi, M.; Luizon, C.; Urbanski, J.; Cussac, V. Reproduction of landlocked Aplochiton zebra Jenyns (Pisces, Galaxiidae). Ecol. Freshw. Fish 2008, 17, 394-405. [CrossRef]

70. Pollard, D.A. The biology of a landlocked form of the normally catadromous salmoniform fish Galaxias maculatus (Jenyns). I. Life cycle and origin. Aust. J. Mar. Freshw. Res. 1971, 22, 91-123. [CrossRef]

71. Chapman, A.; Morgan, D.L.; Beatty, S.J.; Gill, H.S. Variation in life history of land-locked lacustrine and riverine populations of Galaxias maculatus (Jenyns 1842) in Western Australia. Environ. Biol. Fish. 2006, 77, 21-37. [CrossRef]

72. Waters, J.M.; López, J.A.; Wallis, G.P. Molecular phylogenetics and biogeography of galaxiid fishes (Osteichthyes: Galaxiidae): Dispersal, vicariance, and the position of Lepidogalaxias salamandroides. Syst. Biol. 2000, 49, 777-795. [CrossRef]

73. Boy, C.C.; Morriconi, E.; Calvo, J. Reproduction in puyen, Galaxias maculatus (Pisces: Galaxiidae), in the southernmost extreme of distribution. J. Appl. Ichthyol. 2007, 23, 547-554. [CrossRef] 
74. Milano, D.; Barriga, J.P. Reproductive aspects of Galaxias platei (Pisces, Galaxiidae) in a deep lake in North Patagonia. Mar. Freshw. Res. 2018, 69, 1379-1388. [CrossRef]

75. Laurenson, L.J.B.; French, R.P.; Jones, P.; Ierodiaconou, D.; Gray, S.; Versace, V.L.; Rattray, A.; Brown, S.; Monk, J. Aspects of the biology of Galaxias maculatus. J. Fish Biol. 2012, 81, 1085-1100. [CrossRef] [PubMed]

76. McDowall, R.M. Galaxias maculatus (Jenyns), the New Zealand Whitebait. N. Z. Mar. Dept. Fish. Res. Bull. 1968, 2, 1-84.

77. Peredo, S.; Sobarzo, C. Actividad gonádica estacional de Galaxias maculatus (Jenyns, 1842) en el Río Cautín, IX Región, Chile. Bol. Soc. Biol. Concep. 1994, 65, 65-70.

78. Barriga, J.P.; Battini, M.A.; Macchi, P.J.; Milano, D.; Cussac, V.E. Spatial and temporal distribution of landlocked Galaxias maculatus and Galaxias platei (Pisces: Galaxiidae) in a Lake in the South American Andes. N. Z. J. Mar. Freshw. Res. 2002, 36, 345-359. [CrossRef]

79. Boy, C.C.; Pérez, A.F.; Lattuca, M.E.; Calvo, J.; Morriconi, E. Reproductive biology of Galaxias maculatus (Jenyns 1842) in the Río Ovando, a high-latitude environment in southernmost Patagonia, Argentina. J. Appl. Ichthyol. 2009, 25, 661-668. [CrossRef]

80. Vigliano, P.H.; Beauchamp, D.A.; Milano, D.; Macchi, P.J.; Alonso, M.F.; García Asorey, M.I.; Denegri, M.A.; Ciancio, J.E.; Lippolt, G.; Rechencq, M.; et al. Quantifying predation on galaxiids and other native organisms by introduced rainbow trout in an ultraoligotrophic lake in northern Patagonia, Argentina: A bioenergetics modeling approach. Trans. Am. Fish. Soc. 2009, 138, 1405-1419. [CrossRef]

81. Milano, D.; Lozada, M.; Zagarese, H.E. Predator-induced reaction patterns of landlocked Galaxias maculatus to visual and chemical cues. Aquat. Ecol. 2010, 44, 741-748. [CrossRef]

82. Cussac, V.E.; Fernández, D.A.; Gómez, S.E.; López, H.L. Fishes of Southern South America: A story driven by temperature. Fish Physiol. Biochem. 2009, 35, 29-42. [CrossRef] [PubMed]

83. Magnuson, J.J. History and heroes: The thermal niche of fishes and long-term lake ice dynamics. J. Fish Biol. 2010, 77, 1731-1744. [CrossRef] [PubMed]

84. Servicio Meteorológico Nacional. Available online: https://www.smn.gob.ar/clima/tendencias (accessed on 16 April 2020).

85. Secretaría de Ambiente y Desarrollo Sustentable de la Nación. Tercera Comunicación Nacional de la República Argentina a la Convención Marco de las Naciones Unidas Sobre el Cambio Climático. 2015. Available online: https://www.argentina.gob.ar/ambiente/sustentabilidad/cambioclimatico/comunicacionnacional/ tercera (accessed on 24 March 2020).

86. Pascual, M.A.; Cussac, V.; Dyer, B.; Soto, D.; Vigliano, P.; Ortubay, S.; Macchi, P. Freshwater fishes of Patagonia in the 21st century after a hundred years of human settlement, species introductions, and environmental change. Aquat. Ecosyst. Health Manag. 2007, 10, 212-227. [CrossRef]

87. Macchi, P.J.; Cussac, V.E.; Alonso, M.F.; Denegri, M.A. Predation relationships between introduced salmonids and the native fish fauna in lakes and reservoirs in Northern Patagonia. Ecol. Freshw. Fish 1999, 8, 227-236. [CrossRef]

88. Cussac, V.E.; Becker, L.A.; Aigo, J.; Conte-Grand, C.; Blasetti, G.; Cordero, P.; Crichigno, S.; Nabaes, D. Abundance of native fishes, wild introduced salmonids, and escaped farmed rainbow trout in a Patagonian reservoir. Lakes Reserv. Res. Manag. 2014, 19, 74-85. [CrossRef]

89. Nabaes Jodar, D.N.; Becker, L.A.; Cordero, P.; Blasetti, G.; Cussac, V.E. Native and exotic fishes in a Patagonian reservoir with rainbow trout cage culture: Spatial and trophic resource use. Knowl. Manag. Aquat. Ecosyst. 2017, 418, 33. [CrossRef]

90. Nabaes Jodar, D.N.; Cussac, V.E.; Becker, L.A. Into the wild: Escaped farmed rainbow trout show a dispersal-associated diet shift towards natural prey. Hydrobiologia 2020, 847, 105-120. [CrossRef]

91. Zambrano, L.; Martínez-Meyer, E.; Menezes, N.; Townsend Peterson, A. Invasive potential of common carp (Cyprinus carpio) and Nile tilapia (Oreochromis niloticus) in American freshwater systems. Can. J. Fish. Aquat. Sci. 2006, 63, 1903-1910. [CrossRef]

92. Aigo, J. Interacción Entre Peces Nativos y Salmónidos en Patagonia: Su Vulnerabilidad Frente al Cambio Climático. Ph.D. Thesis, Universidad Nacional del Comahue, Bariloche, Argentina, 2010.

93. Alvear, P.; Rechencq, M.; Macchi, P.J.; Alonso, M.F.; Lippolt, G.E.; Denegri, M.A.; Navone, G.; Zattara, E.; García Asorey, M.I.; Vigliano, P.H. Composición, distribución y relaciones tróficas de la ictiofauna del río Negro, Patagonia Argentina. Ecol. Austral 2007, 17, 231-246. 
94. Tagliaferro, M.; Quiroga, A.; Pascual, M. Spatial pattern and habitat requirements of Galaxias maculatus in the last un-interrupted large river of Patagonia: A baseline for management. Environ. Nat. Resour. Res. 2014, 4. [CrossRef]

95. Moorman, M.C.; Eggleston, D.B.; Anderson, C.B.; Mansilla, A.; Szejner, P. Implications of beaver Castor canadensis and trout introductions on native fish in the Cape Horn Biosphere Reserve, Chile. Trans. Am. Fish. Soc. 2009, 138, 306-313. [CrossRef]

96. Ferriz, R.A.; Salas Aramburu, W.; Gómez, S.E.; Menni, R.C. Morphological differences in Galaxias maculatus (Jenyns, 1842) population, an osmeriform fish from Southern Argentina. Bioikos 2001, 15, 83-89.

97. Ondarza, P.M.; Miglioranza, K.S.B.; Gonzalez, M.; Shimabukuro, V.M.; Aizpún, J.E.; Moreno, V.J. Organochlorine compounds in common carp (Cyprinus carpio) from Patagonia Argentina. J. Braz. Soc. Ecotoxicol. 2010, 5, 41-47. [CrossRef]

98. Ondarza, P.M.; Gonzalez, M.; Fillmann, G.; Miglioranza, K.S.B. Increasing levels of persistent organic pollutants in rainbow trout (Oncorhynchus mykiss) following a mega-flooding episode in the Negro River basin, Argentinean Patagonia. Sci. Total Environ. 2012, 419, 233-239. [CrossRef] [PubMed]

99. Ondarza, P.M.; Gonzalez, M.; Fillmann, G.; Miglioranza, K.S.B. PBDEs, PCBs and organochlorine pesticides distribution in edible fish from Negro River basin, Argentinean Patagonia. Chemosphere 2014, 94, 135-142. [CrossRef] [PubMed]

100. Martínez, O.A.; Kutschker, A. The 'Rodados Patagónicos' (Patagonian shingle formation) of eastern Patagonia: Environmental conditions of gravel sedimentation. Biol. J. Linn. Soc. 2011, 103, 336-345. [CrossRef]

101. Aragón, E.; Goin, F.J.; Aguilera, Y.E.; Woodburne, M.O.; Carlini, A.A.; Roggiero, M.F. Palaeogeography and palaeoenvironments of northern Patagonia from the Late Cretaceous to the Miocene: The Palaeogene Andean gap and the rise of the North Patagonian High Plateau. Biol. J. Linn. Soc. 2011, 103, 305-315. [CrossRef]

102. Benito, G.; Thorndycraft, V.R. Catastrophic glacial-lake outburst flooding of the Patagonian Ice Sheet. Earth-Sci. Rev. 2020, 200, 102996. [CrossRef]

(C) 2020 by the authors. Licensee MDPI, Basel, Switzerland. This article is an open access article distributed under the terms and conditions of the Creative Commons Attribution (CC BY) license (http://creativecommons.org/licenses/by/4.0/). 